${ }^{c}$ Rehabilitación Cardiaca, Hospital Universitario de Torrejón, Torrejón de Ardoz, Madrid, España

d Servicio de Neumología, Hospital Universitario de Torrejón, Torrejón de Ardoz, Madrid, España

* Autor para correspondencia. Servicio de Cardiología, Hospital Universitario de Torrejón, C/ Mateo Inurria, s/n, 28850 Madrid, España; Teléfono: +34 916262626; Ext.; 5709; Fax: +34 914886624 .
Correo electrónico: eduar.alegria@gmail.com

(E. Alegría-Barrero).

http://dx.doi.org/10.1016/j.acmx.2016.10.002

1405-9940

(c) 2016 Instituto Nacional de Cardiología Ignacio Chávez. Publicado por Masson Doyma México S.A. Este es un artículo Open Access bajo la licencia CC BY-NC-ND (http: / / creativecommons.org/licenses/bync-nd/4.0/).

\section{Lethal Fournier gangrene following cardiac surgery with cardiopulmonary bypass}

\section{Gangrena de Fournier letal tras cirugía cardiaca con circulación extracorpórea}

Fournier's gangrene (FG) is a grave disease that consists in a necrotizing fasciitis and gangrene with over infection of the perineum and genitalia. ${ }^{1}$ This case involves the observation of this disease in the postoperative course of a patient after reoperation for replacement of a mitral valve prosthesis.

\section{Case report}

A 73 year-old man with history of Diabetes Mellitus (DM), colonic polyp resection and uretheral carcinoma treated by chemotherapy, was admitted in our surgical unit. He was recently diagnosed and medically treated (3 coronary stents) in other hospital of an acute myocardial infarction complicated with severe left ventricular dysfunction and ischemic mitral regurgitation. He was referred for mitral valve surgery. On March 2010, using standards techniques of Cardiac Surgery with Cardiopulmonary Bypass (CPB), he underwent emergent mitral valve replacement with a 27 Sorin Pericarbon More bioprosthesis (Sorin Group, USA). Early in the postoperative course, he needed a new open heart surgery to successfully repair a periprosthetic mitral leak. The patient had an stormy and prolonged postoperative course in the Intensive Care Unit (ICU) with need of inotropic support, long mechanical ventilation and renal replacement therapy with ultrafiltration and dialysis. He was discharged from the ICU to the ward and submitted to a long rehabilitation process. On august 2010, a new significant symptomatic dysfunction with insufficiency in the mitral prosthesis valve was detected by echocardiogram. Subsequently, a third CPB heart operation was decided and performed. The dysfunctional mitral prosthesis valve was replaced for a new 27 Pericarbon More Sorin tissue valve. At surgery, no signs of prosthetic valve infection or endocarditis was constated. The cultures of peripheral blood and of the explanted prosthesis were negative for bacterial and fungal grow. The operation was complicated with postoperative bleeding and coagulopathy, high dose of inotropics drugs, prolonged mechanical ventilation and kidney failure with ultrafiltration. The postoperative transthoracic echocardiograms showed normal function of the mitral valve and moderate left ventricular dysfunction. The patient condition progressively deteriorated and developed severe septic shock with not a clear origin. The blood cultures were negative. FG was diagnosed by physical examination in the ICU (Fig. 1). The patient was treated with high dose of intravenous broad spectrum antibiotics and was urgently submitted to a surgical extensive perineal debridement. In spite of that, the patient died in refractory sepsis $2 \mathrm{~h}$ later in the 28 postoperative day.

FG is a serious and progressing fasciitis with polymicrobial infection of the genitalia and perineal soft tissue. ${ }^{1}$ Is more commonly presented in adult men. The more

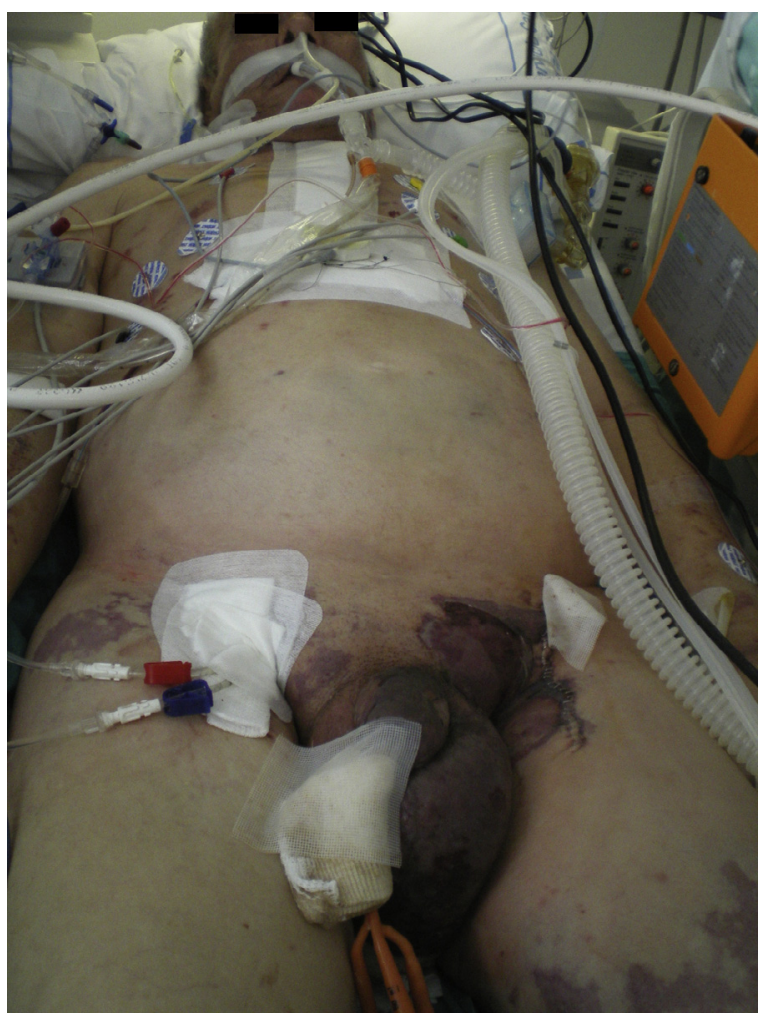

Figure 1 Picture taken in the Intensive Care Unit Just before transfer the patient to the operating room for a perineal debridement. Necrosis of the skin of the scrotum, pennies and part of the left groin is clearly appreciated. Finding consistent with the diagnosis of Fournier's gangrene. 
frequent predisposing factors are immunosuppressant conditions and diseases, DM, Alcohol abuse, old age, HIV infection, malnutrition, citotoxic drugs, chronic diseases, peripheral arteriopathy, hepatopathy, nephropathy, morbid obesity, homosexuality, and other. 2,3 The etiology can be idiopathic in about $25 \%$ of the patients, in the remaining is more commonly observed following colo-rectal surgery, urologic procedures and perineal, ano-genital, pelvic and abdominal diseases, infections, trauma or surgery. Moreover has been reported after circumcision, masturbation, vasectomy, anal impalement and procedures in the genitalia as piercing, tattoo, infiltrations, implants and prosthesis. ${ }^{1-3}$ The pathophysiology is in relation with a endoarteritis and thrombosis of the small arteries of the perineal affected area with hypoperfusion and hypoxia that lead to necrosis and infection. The infecting microorganisms produce enzymes (heparinase, hyalorudinase, streptokinase, urokinase, lecithinase, collagenase) and cytokines which digest and eliminate the fascias. A rapid spread of the necrosis and infection of the skin and subcutaneous tissue is typical of the disease. Characteristically, the infection is of a polymicrobial nature with both aerobic and anaerobic bacteria. ${ }^{1}$ The diagnosis is based in clinical findings, furthermore can be supplemented with ultrasound examination, computed tomography and magnetic resonance imaging. The cornerstone of treatment is an early extensive surgical debridement and the administration of high dose of antibiotics. Despite of that, the mortality rate remains high and can be estimated in $10-40 \% .^{1-3}$ Heart operations using CPB expose the patient to a significant surgical stress, inflammatory response, endotoxemia and immunosuppressive state. This situation predispose the patients to the development of infections. We believe, that in our case, the impact of 3 cardiac operations with CPB associate with other co-morbid conditions, could be the most important contributing factor in the development of this often deadly disease. FG in relation with heart surgery is very uncommon. In a review of the literature, using Medline and other data base, we only found 2 reported cases. The first case, an adult man after an on-pump coronary artery bypass graft surgery with full recovery after debridement and assisted - vacuum therapy. ${ }^{4}$ The second case a pediatric patient after first stage repair of a pulmonary atresia with ventricular septal defect, the patient also survived the postoperative FG complication, we do not know if the patient was operated with or without extracorporeal circulation. ${ }^{5}$ Despite the fact that FG is very infrequently associated with cardiac surgery, that eventuality should be keep in mind among physicians taken care of postoperative heart surgery patients. An early recognition and intervention can provide opportunities to improve outcomes in these patients.

\section{Financing}

The authors did not receive any payment or economical benefit for the preparation and execution of the article.

\section{Conflict of interests}

The authors declare do not have conflict of interest.

\section{Acknowledgements}

The authors want to thank the technical assistance of Carlos C. Abad Torres, Student, Canterbury School, Las Palmas de Gran Canaria, Spain.

\section{Bibliografía}

1. Chennamselty A, Khourdaji I, Burks F, et al. Contemporary diagnosis and management of Fournier's gangrene. Ther Adv Urol. 2015; 7:203-15

2. Mallikarjuna MN, Vijayakumar A, Patil VS, et al. Fournier gangrene: current practices. ISRN Surg. 2012:942437, http://dx.doi. org/10.5402/2012/942437. Published on line 2012 December 3.

3. Garcia- Martin A, Turégano-Fuentes F, Cuadrado-Ayuso M, et al. Factores predictivos de mortalidad en la gangrena de Fournier. Cir Esp. 2015;93:12-7.

4. Usta S, Basbug HS. Fournier's gangrene following coronary artery bypass surgery: should extracorporeal circulation be blamed? Ulutas J. 2015;1:81-5.

5. Jaworski R, Haponiuk I, Irga-Jaworska N, et al. Fungal infection in children in the early postoperative period after cardiac surgery for congenital heart disease: single-center experience. Interact Cardiovasc Thorac Surg. 2016;23:431-7.

Cipriano Abad*, Stefano Urso, José Ángel López-Ruiz, María Ángeles Tena, Jaime Serna, Juan José Feijoo-Osorio

Service of Cardiac Surgery, University Hospital Gran Canaria Dr Negrin, Las Palmas de Gran Canaria, Spain

* Corresponding author at: Service of Cardiac Surgery, University Hospital Gran Canaria Dr Negrin, Calle Barranco de La Ballena sn, Las Palmas de Gran Canaria 35010, Spain. E-mail address: cprnabad2@gmail.com (C. Abad).

http://dx.doi.org/10.1016/j.acmx.2016.11.005

$1405-9940$

(c) 2016 Instituto Nacional de Cardiología Ignacio Chávez. Published by Masson Doyma México S.A. This is an open access article under the CC BY-NC-ND license (http://creativecommons.org/licenses/by-nc$\mathrm{nd} / 4.0 /$ ). 